\title{
State of Art of the Persuasive Technology using Social Media for Behaviour Change in Malaysia
}

\author{
Mohammad Syukran Kamalruzzaman', Sharkawi Che Din², \\ Anuar Mohd Yusof ${ }^{3}$, Nik Atilla Atasha Shamsuddin ${ }^{4}$ \\ 1 Faculty of Art \& Design, Universiti Teknologi MARA, Shah Alam 40450 Selangor, Malaysia \\ 2 Universiti Malaysia Kelantan, Locked Bag Number 1, Bachok 16300 Kelantan, Malaysia \\ syukran@umk.edu.my, sharkawi237@uitm.edu.my, anuarmy@umk.edu.my, nikatillaatasha@uitm.edu.my \\ Tel: +60199833814
}

\begin{abstract}
Persuasive technology is an evolving form of behaviour change agent that is becoming more popular with the emergence of social media. In $2020,81 \%$ of Malaysians are active social media users who contribute to the escalation of behavioural changes using online platforms. This paper provides a verifiable review of 10 years of persuasive technology using social media for Malaysian healthcare and behavioural changes with the concern to (1) reviewing the effectiveness of persuasive technology using social media to behaviour changes, (2) outlining the technology methods, research methods, strategies, theories and targeted behaviour (3) stating the issues regarding the studied persuasive technologies and (4) highlighting the future research recommendation.
\end{abstract}

Keywords: Persuasive technology, behavioural change, social media

eISSN: 2398-4287 @ 2021. The Authors. Published for AMER ABRA CE-Bs by e-International Publishing House, Ltd., UK. This is an open-access article under the CC BYNC-ND license (http://creativecommons.org/licenses/by-nc-nd/4.0). Peer-review under responsibility of AMER (Association of Malaysian Environment-Behaviour Researchers), ABRA (Association of Behavioural Researchers on Asians) and cE-Bs (Centre for Environment-Behaviour Studies), Faculty of Architecture, Planning \& Surveying, Universiti Teknologi MARA, Malaysia.

DOI: https://doi.org/10.21834/ebpj.v6iSl6.3035

\subsection{Introduction}

Persuasive technology (PT) is a system that is designed and developed using the principle of persuasive design, which aims to modify a certain attitude of behaviour using social theories such as persuasion, social influence and not through physical force. In the last ten years, PT has been used in various fields impacting one or more aspects of health and behaviour change. Researchers have summarized two main areas of PT, which are (1) health management and prevention (Almonani, Husain, San, Almomani, \& Al-Betar, 2014) and (2) disease management (Aziz, Salleh, Yusof, \& Roseli, 2017).

PT for health prevention and promotion are focused on behaviours by individuals for the motivation of avoiding illness, detecting preillness symptoms, and supporting general wellbeing (Orji, Vassileva, \& Mandryk, 2014). This includes healthy behaviours such as nutritional food intake (Salim, Ali, \& Noah, 2017), obesity prevention (Yahaya \& Hashim, 2018), environmental issues awareness (W. N. W. Ahmad \& Ali, 2018), sex education (Oyibo, Orji, \& Vassileva, 2017) and children dental health (Puad, Rahim, Firdaus, Sayedi, \& Mohadis, 2019). PT for disease management targets individuals to improve self-management healthcare skills such as guiding them to manage specific illnesses, teaching them to get proper treatment and medical appointments, as well as helping them to make a certain decision in their healthcare treatment (Qasim, Ahmad, Omar, Zulkifli and Bakar, 2017).

There were trends of increasing health awareness among Malaysian social media (SM) users. Stakeholders, government agencies, ministries, designers, practitioners, and developers have introduced persuasive technology to trigger targeted behaviours among patients and individuals. Consequently, an empirical review reveals the trends, research gap, best practices, and future direction in research in PT

eISSN: 2398-4287 (C 2021. The Authors. Published for AMER ABRA cE-Bs by e-International Publishing House, Ltd., UK. This is an open-access article under the CC BYNC-ND license (http://creativecommons.org/licenses/by-nc-nd/4.0/). Peer-review under responsibility of AMER (Association of Malaysian Environment-Behaviour Researchers), ABRA (Association of Behavioural Researchers on Asians) and cE-Bs (Centre for Environment-Behaviour Studies), Faculty of Architecture, Planning \& Surveying, Universiti Teknologi MARA, Malaysia.

DOI: https://doi.org/10.21834/ebpj.v6iSl6.3035 
used. This paper will be highlighting a review of 10 years of empirical review of 10 years of persuasive technology using social media for Malaysian healthcare and behavioural changes. This paper will be discussing essential aspects such as (1) the effectiveness.

\begin{tabular}{|ll}
\hline Nomenclature \\
PT & Persuasive technology \\
SM & Social media \\
ICT & Information and communication technology
\end{tabular}

\subsection{Literature Review}

\subsection{Persuasive Technology}

Persuasive Technology (PT) uses three persuasion factors: motivation, ability, and trigger (Brian J Fogg, 2002). A persuasive system must offer a proper motivational manner, ease of use and stimuli which initiate the behaviour incentive to the users to To influence the positive behaviour (Brain J Fogg, 2009).

A PT is successful when it can persuade people to change from one state to a more well-known state (Wan Ahmad and Ali, 2018). Previous research has shown that social influence or social factor is a strong motivator of healthy behaviour change (Oyibo et al., 2017). Researchers are also aware that information and communication technology (ICT) plays a crucial role in affecting an individual's thinking, behaviour and decision making (Aziz et al., 2017). Therefore, researchers intend to use SM as the main medium of PT to influence as many people while exploiting the effectiveness of social influence.

\subsection{Social Media as Persuasive Technology}

In various fields, PT in social media (SM) is used to influence certain behaviours which will benefit the stakeholders, such as in business (Hassan, Shiratuddin, \& Ab Salam, 2015), education (Z. Ahmad, Ab Rahim, \& Ya'acob, 2019), higher education, e-commerce (Hamid, Cheun, Abdullah, Ahmad, \& Ngadiman, 2019), informal learning (Al-Sabaawi \& Dahlan, 2019), pro-environmental behaviour (Taha, Wu, Emeakaroha, Krabicka, \& Lee, 2017), public relation (Z. A. Ahmad, 2019), productivity (Ishak, Khairuddin, \& Aziz, 2020), politics (Butt, Saleem, Siddiqui, Saleem, \& Awang, 2021) and healthcare (Z. Ahmad et al., 2019). With the emergence of social sites like Facebook, WhatsApp, Instagram, and many others, $81 \%$ of Malaysians have become active SM users (Miller, 2021). We also identified persuasive design frameworks which will be giving positive behaviour effects towards various demographic groups, especially in global smartphone applications (Faisal, Nor and Abdullah, 2019), virtual reality (Çakiroğlu and Gökoğlu, 2019), and social media engagement (Muhamad \& Shahrom, 2020). The vast development of social activities in the ICT platform allows PT to become more dominant as a social influencer for positive behaviour change.

\subsection{Methodology}

We use quantitative content analysis of PT in SM in the Malaysian context to systematically analyze the state-pf-art of the studied field. This method allows comparing, contrasting, and categorizing the data according to different themes and concepts (Stinson, 2021). For the literature search, we used a few journal databases to ensure appropriate coverage of technological intervention of PT in behavioural change in various fields such as education, healthcare, health management, productivity, business and other related areas. Those databases include Google Scholars, Elsevier, PubMed, IEEE Xplore and Springer. We have narrowed down the search in the Malaysian context to ensure the achievement of the research objectives. Our search key terms are "Persuasive Technology in Malaysia", "Persuasive Technology in Malaysian Social Media", "Social Media Behavioural Change in Malaysia", and "Malaysian Behaviour Change using Persuasive Technology". After obtaining the number of unique articles, we applied the two-stage filtering process for the title and abstract of each article, as shown in Figure 1. The coding schemes are as shown in Table 1.

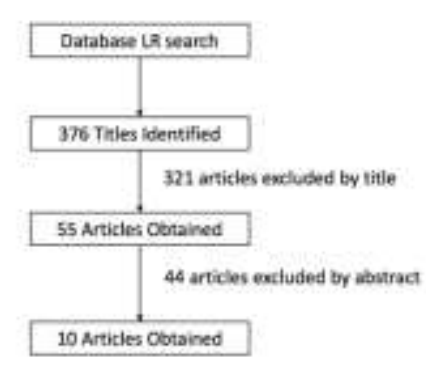

Fig. 1. Articles Identification Process 


\begin{tabular}{lll}
\hline S/ & Codes & Items \\
$\mathrm{N}$ & & \\
\hline 1 & Trends & Categories of PT using SM for behavioural changes \\
2 & Effectiveness & A positive, partially positive or negative study \\
3 & Strategies & Motivational strategies used. \\
4 & Behaviour Theories & $\begin{array}{l}\text { Theory of planned behaviour, dual coding theory } \\
\text { etc. }\end{array}$ \\
& & Weight loss, physical activity, heart problems etc. \\
5 & Behaviour Outcomes & Older, adult, young adult, children etc. \\
6 & Target group & Qualitative, quantitative and mixed-method \\
\hline
\end{tabular}

\subsection{Findings}

In this stage, we identified ten (10) research papers that indicate the state-of-art of persuasive technology using social media studies in Malaysia. To simplify the findings, we presented the data in a detailed summary of all unique research reviewed. We use categories which include the author) names, PT projects, targeted behaviour domains, the technology used, motivational strategies, behaviour theories applied, and the result obtained as shown in Table 2/

\subsection{Trends of Persuasive Technology using Social Media}

Table 2. Effectiveness of PT using social media in Malaysia

\begin{tabular}{|c|c|c|c|c|c|c|}
\hline Arthur & PT Project & $\begin{array}{l}\text { Behaviour } \\
\text { Domain }\end{array}$ & Technology & Strategy & Behaviour Theory & Result \\
\hline $\begin{array}{l}\text { (Almonani et } \\
\text { al., 2014) }\end{array}$ & $\begin{array}{l}\text { MACO Online } \\
\text { Game }\end{array}$ & $\begin{array}{l}\text { Healthy } \\
\text { lifestyle }\end{array}$ & Mobile game & $\begin{array}{l}\text { Tracking, } \\
\text { monitoring } \\
\text { and reminder }\end{array}$ & Not specified & $\begin{array}{l}\text { Partially } \\
\text { positive }\end{array}$ \\
\hline $\begin{array}{l}\text { (Hamid et al., } \\
\text { 2019) }\end{array}$ & $\begin{array}{l}\text { Acceptance of } \\
\text { e-Commerce } \\
\text { site }\end{array}$ & $\begin{array}{l}\text { Product } \\
\text { purchase }\end{array}$ & E-commerce & $\begin{array}{l}\text { Social } \\
\text { support and } \\
\text { social } \\
\text { influence }\end{array}$ & User acceptance & Positive \\
\hline $\begin{array}{l}\text { (Hassan et } \\
\text { al., 2015) }\end{array}$ & $\begin{array}{l}\text { Social media } \\
\text { business } \\
\text { survey }\end{array}$ & $\begin{array}{l}\text { Product } \\
\text { purchase }\end{array}$ & Social network & Not specified & $\begin{array}{l}\text { Perceived impact of social } \\
\text { media as a PT }\end{array}$ & Positive \\
\hline $\begin{array}{l}\text { (Ishak et al., } \\
2020)\end{array}$ & $\begin{array}{l}\text { Social media } \\
\text { survey }\end{array}$ & $\begin{array}{l}\text { Social media } \\
\text { usage }\end{array}$ & Social network & Feedback & Not specified & $\begin{array}{l}\text { Partially } \\
\text { positive }\end{array}$ \\
\hline $\begin{array}{l}\text { (Mohamad, } \\
\text { Yahaya, \& } \\
\text { Wahid, 2018) }\end{array}$ & $\begin{array}{l}\text { Mobile assistive } \\
\text { technology }\end{array}$ & $\begin{array}{l}\text { Healthy } \\
\text { lifestyle }\end{array}$ & Mobile apps & $\begin{array}{l}\text { Tracking and } \\
\text { monitoring }\end{array}$ & Not specified & Positive \\
\hline $\begin{array}{l}\text { (Muhamad \& } \\
\text { Shahrom, } \\
\text { 2020) }\end{array}$ & $\begin{array}{l}\text { Social media } \\
\text { survey }\end{array}$ & $\begin{array}{l}\text { Social media } \\
\text { engagement }\end{array}$ & Social network & $\begin{array}{l}\text { Social } \\
\text { influence and } \\
\text { feedback }\end{array}$ & $\begin{array}{l}\text { Social media engagement } \\
\text { behaviour }\end{array}$ & Positive \\
\hline $\begin{array}{l}\text { (Nawi, Nasir, } \\
\text { \& Al Mamun, } \\
\text { 2016) }\end{array}$ & $\begin{array}{l}\text { Social media } \\
\text { survey }\end{array}$ & $\begin{array}{l}\text { Choosing } \\
\text { business } \\
\text { platform }\end{array}$ & Social network & $\begin{array}{l}\text { Social } \\
\text { influence and } \\
\text { feedback }\end{array}$ & $\begin{array}{l}\text { Unified Theory of } \\
\text { Acceptance and Use of } \\
\text { Technology }\end{array}$ & Positive \\
\hline $\begin{array}{l}\text { (Noor \& } \\
\text { Shahrom, } \\
\text { 2021) }\end{array}$ & $\begin{array}{l}\text { Social media } \\
\text { survey }\end{array}$ & $\begin{array}{l}\text { Job } \\
\text { performance }\end{array}$ & Social network & Feedback & $\begin{array}{l}\text { Employee job } \\
\text { Performance }\end{array}$ & Positive \\
\hline $\begin{array}{l}\text { (Rahman, } \\
2016)\end{array}$ & Charity Video & Charity & Social network & Feedback & Not specified & Positive \\
\hline $\begin{array}{l}\text { (Salim et al., } \\
\text { 2017) }\end{array}$ & $\begin{array}{l}\text { Nutrihealth } \\
\text { Mobile Apps }\end{array}$ & $\begin{array}{l}\text { Healthy } \\
\text { lifestyle }\end{array}$ & Mobile game & $\begin{array}{l}\text { Tracking and } \\
\text { monitoring }\end{array}$ & $\begin{array}{l}\text { Unified Theory of } \\
\text { Acceptance and Use of } \\
\text { Technology }\end{array}$ & Positive \\
\hline
\end{tabular}

\subsection{Effectiveness of Persuasive Technology using Social Media}

Table 3. Effectiveness of PT using social media in Malaysia

\begin{tabular}{llll}
\hline Outcome & Study & Total & Overall (\%) \\
\hline Positive & (Hassan et al., 2015), (Hamid et al., 2019), (Rahman, 2016), & 8 & 80 \\
& (Muhamad \& Shahrom, 2020), (Mohamad et al., 2018), & & \\
& Nawi, Nasir, \& Al Mamun, 2016), (Noor \& Shahrom, 2021), & & \\
& (Salim et al., 2017) & 2 & 20 \\
Partially positive & (Ishak et al., 2020), (Almonani et al., 2014) & 0 & 0 \\
Negative & & 0 \\
\hline
\end{tabular}

$80 \%$ of the reviewed papers appear to be positively affecting the targeted behaviour. $20 \%$ of the research did not show an entirely positive effect towards the aimed behaviour. However, all reviewed papers do not represent the negative effect of social media, which acts as persuasive technology for behavioural change in Malaysia.

\subsection{Persuasive Technology Strategies}


Table 4. Persuasive, motivational strategies

\begin{tabular}{|c|c|c|c|c|}
\hline Strategies & Studies with a positive result & $\begin{array}{l}\text { Studies with a } \\
\text { partially positive } \\
\text { result }\end{array}$ & $\begin{array}{ll}\text { Studies with } & \text { Total } \\
\text { Negative Results } & \end{array}$ & $\begin{array}{l}\text { Overall } \\
(\%)\end{array}$ \\
\hline Feedback & $\begin{array}{l}\text { (Rahman, 2016), (Noor \& } \\
\text { Shahrom, 2021) }\end{array}$ & $\begin{array}{l}\text { Ishak et al., } \\
\text { 2020) }\end{array}$ & 0 & 30 \\
\hline $\begin{array}{l}\text { Social support and social } \\
\text { influence }\end{array}$ & (Hamid et al., 2019) & & 0 & 10 \\
\hline $\begin{array}{l}\text { Social influence and } \\
\text { feedback }\end{array}$ & $\begin{array}{l}\text { (Muhamad \& Shahrom, 2020), } \\
\text { (Nawi et al., 2016), }\end{array}$ & & 0 & 20 \\
\hline $\begin{array}{l}\text { Tracking and } \\
\text { monitoring }\end{array}$ & $\begin{array}{l}\text { (Salim et al., 2017), } \\
\text { (Mohamad et al., 2018) }\end{array}$ & & 0 & 20 \\
\hline $\begin{array}{l}\text { Tracking, monitoring } \\
\text { and reminder. }\end{array}$ & & $\begin{array}{l}\text { (Almonani et al., } \\
\text { 2014) }\end{array}$ & 0 & 10 \\
\hline Not specified & (Hassan et al., 2015) & & 0 & 10 \\
\hline
\end{tabular}

Data in Table 4 showed that feedback has the highest percentage with 30\%, followed by social influence and feedbacks and tracking and monitoring at $20 \%$. The rest of the strategies has $10 \%$ coverage, respectively.

\subsection{Persuasive Technology Behaviour Theories}

Table 5. Persuasive behaviour theories

\begin{tabular}{|c|c|c|c|c|c|}
\hline Behaviour Theory & Studies with a positive result & $\begin{array}{l}\text { Studies with a partially } \\
\text { positive result }\end{array}$ & $\begin{array}{l}\text { Studies with } \\
\text { Negative Results }\end{array}$ & Total & $\begin{array}{l}\text { Overall } \\
(\%)\end{array}$ \\
\hline $\begin{array}{l}\text { Employee job } \\
\text { Performance }\end{array}$ & (Noor \& Shahrom, 2021) & & 0 & 1 & 10 \\
\hline Perceive impact of SM & (Hassan et al., 2015) & & 0 & 1 & 10 \\
\hline User acceptance & (Hamid et al., 2019) & & 0 & 1 & 10 \\
\hline $\begin{array}{l}\text { Social media } \\
\text { engagement } \\
\text { behaviour }\end{array}$ & $\begin{array}{l}\text { (Muhamad \& Shahrom, } \\
\text { 2020) }\end{array}$ & & 0 & 1 & 10 \\
\hline $\begin{array}{l}\text { Unified Theory of } \\
\text { Acceptance and Use } \\
\text { of Technology }\end{array}$ & $\begin{array}{l}\text { (Nawi et al., 2016), (Salim et } \\
\text { al., 2017) }\end{array}$ & & 0 & 2 & 20 \\
\hline Not Specified & $\begin{array}{l}\text { (Rahman, 2016), (Ishak et } \\
\text { al., 2020), (Mohamad et al., } \\
\text { 2018) }\end{array}$ & $\begin{array}{l}\text { Ishak et al., 2020), } \\
\text { (Almonani et al., } \\
\text { 2014) }\end{array}$ & 0 & 4 & 40 \\
\hline
\end{tabular}

Most studies of PT using SM in Malaysia does not specify the behavioural theories used. However, the remaining $60 \%$ have specified with the highest percentage is the Unified Theory of Acceptance and Use of Technology.

\subsection{Persuasive Technology Behaviour Outcomes}

Table 6. Persuasive behaviour outcome

\begin{tabular}{|c|c|c|c|c|c|}
\hline Behaviour Outcome & Studies with a positive result & $\begin{array}{l}\text { Studies with a } \\
\text { partially positive } \\
\text { result }\end{array}$ & $\begin{array}{l}\text { Studies with } \\
\text { Negative Results }\end{array}$ & Total & $\begin{array}{l}\text { Overal } \\
\mathrm{I}(\%)\end{array}$ \\
\hline Charity & (Rahman, 2016) & & 0 & 1 & 10 \\
\hline $\begin{array}{l}\text { Choosing business } \\
\text { platform }\end{array}$ & (Nawi et al., 2016) & & 0 & 1 & 10 \\
\hline Healthy lifestyle & $\begin{array}{l}\text { (Salim et al., 2017), (Mohamad et } \\
\text { al., 2018) }\end{array}$ & $\begin{array}{l}\text { (Almonani et al., } \\
\text { 2014) }\end{array}$ & 0 & 3 & 30 \\
\hline Job performance & (Noor \& Shahrom, 2021) & & 0 & 1 & 10 \\
\hline Product Purchase & $\begin{array}{l}\text { (Hassan et al., 2015), (Hamid et al., } \\
\text { 2019) }\end{array}$ & & 0 & 2 & 20 \\
\hline $\begin{array}{l}\text { Social media } \\
\text { engagement }\end{array}$ & (Muhamad \& Shahrom, 2020) & & 0 & 1 & 10 \\
\hline Social media usage & & $\begin{array}{l}\text { (Ishak et al., } \\
2020 \text { ), }\end{array}$ & 0 & 1 & 10 \\
\hline
\end{tabular}

Behaviour outcome is the final target or objective of a persuasive system. Researchers' most frequent behaviour is a healthy lifestyle with $30 \%$, followed by product purchase behaviour with $20 \%$. The rest of the behaviour outcomes are a charity, choosing a business platform, job performance, social media engagement and social media usage.

\subsection{Persuasive Technology Target Group}

Table 7: Persuasive behaviour outcome

\begin{tabular}{lllll}
\hline Target group & Studies with a positive result & $\begin{array}{l}\text { Studies with a } \\
\text { partially positive } \\
\text { result }\end{array}$ & $\begin{array}{l}\text { Studies with } \\
\text { Negative Results }\end{array}$ & $\begin{array}{c}\text { Total } \\
\text { Overal } \\
\text { I } \%)\end{array}$ \\
\hline
\end{tabular}




\begin{tabular}{|c|c|c|c|c|c|}
\hline Children & & $\begin{array}{l}\text { (Almonani et } \\
\text { al., 2014) }\end{array}$ & 0 & 1 & 10 \\
\hline E-commerce users & (Hamid et al., 2019) & & 0 & 1 & 10 \\
\hline Elderly & (Salim et al., 2017) & & 0 & 1 & 10 \\
\hline Social media users & $\begin{array}{l}\text { (Hassan et al., 2015), (Rahman, } \\
\text { 2016), (Muhamad \& Shahrom, } \\
2020),(\text { Noor \& Shahrom, 2021) }\end{array}$ & $\begin{array}{l}\text { (Ishak et al., } \\
\text { 2020) }\end{array}$ & 0 & 5 & 50 \\
\hline Entrepreneur students & (Nawi et al., 2016) & & 0 & 1 & 10 \\
\hline Visually impaired children & (Mohamad et al., 2018) & & 0 & 1 & 10 \\
\hline
\end{tabular}

In Table 7, we recorded that half of the research targets social media users. The other target respectively presents $10 \%$ of all PT using SM in Malaysia.

\subsection{Persuasive Technology Evaluation Methodologies}

\begin{tabular}{|c|c|c|c|c|c|}
\hline Methodologies & Studies with a positive result & $\begin{array}{l}\text { Studies with a } \\
\text { partially positive } \\
\text { result }\end{array}$ & $\begin{array}{l}\text { Studies with Negative } \\
\text { Results }\end{array}$ & Total & $\begin{array}{l}\text { Overall } \\
(\%)\end{array}$ \\
\hline Quantitative & $\begin{array}{l}\text { (Hassan et al., 2015), (Hamid } \\
\text { et al., 2019), (Rahman, } \\
\text { 2016), (Nawi et al., 2016) } \\
\text { (Muhamad \& Shahrom, } \\
\text { 2020), (Noor \& Shahrom, } \\
\text { 2021), (Salim et al., 2017) }\end{array}$ & $\begin{array}{l}\text { (Ishak et al., } \\
\text { 2020), (Almonani } \\
\text { et al., 2014) }\end{array}$ & 0 & 9 & 90 \\
\hline Qualitative & (Mohamad et al., 2018) & & 0 & 1 & 10 \\
\hline Mixed & & & 0 & 0 & \\
\hline
\end{tabular}

The quantitative method seems to be the chosen methodology by the researchers with a total of $80 \%$. While qualitative methods cover $20 \%$, none of the mixed methods is found in Malaysia for PT using SM for behavioural change.

\subsection{Discussion}

From the findings, PT using SM for behavioural change is effective in the Malaysian context. Malaysia since we found that $80 \%$ of the research is effective. Malaysia has the highest number of active social media users, $81 \%$ of the population by 2020 . The social influence will significantly have a higher tendency to occur with that frequency, thus promoting the positive behaviour change.

However, in the local context, a study that includes social media persuasion is minimal. Most researchers, stakeholders and developers only focused on the PT in other ICT platforms such as e-learning, general healthcare, website, computer programs, and other electronic media. With a considerable number of active SM users nationwide, we would explore more in-depth PT.

While we managed to use creative motivation strategies such as user feedback, social supports, tracking, monitoring and reminders, worldwide researchers have been practising many other persuasive strategies such as competition and leaderboards, video-based persuasion, persuasive text messages, achievement sharing, social learning, virtual rehearsal, self-monitoring, social facilitation, cooperation and collaboration, positive feedbacks and objective reward.

PT is a technological platform with the main focus to generate effective behavioural outcomes. In the body of knowledge of PT using SM in the Malaysian context, we also want to highlight some future research directions such as (1) relationship between persuasion strategies and PT outcome, (2) relationship between target health behaviour to PT outcome and (3) the relationship between behaviour theory and PT outcome.

\subsection{Conclusion}

This paper revised the trends, latest research, and effectiveness of persuasive technology (PT) using social media (SM) in Malaysia from 2011 to 2021. We found that PT has a favourable approach for promoting positive behaviour change in various fields such as healthy lifestyle, business, charity, and other forms of social engagement. However, the research is still limited very small amount of study in Malaysia despite the enormous numbers of SM users.

\section{Acknowledgement}

My sincere thanks to my research supervisors, families, and colleagues at Universiti Malaysia Kelantan and Universiti Teknologi MARA for your continuous support.

\section{References}


Ahmad, Z., Ab Rahim, N. Z., \& Ya'acob, S. (2019). Persuasive system design: social support elements to influence Malaysian wellness in social media. Procedia Computer Science, 161, 773-780.

Ahmad, Z. A. (2019). Embracing social media: The change and disruption to public relations practices in Malaysia. Jurnal Komunikasi: Malaysian Journal of Communication, $35(1)$.

Al-Sabaawi, M. Y. M., \& Dahlan, H. M. (2019). Social Media for Informal Learning Usage in Malaysia: Barriers and Benefits, Cham.

Almonani, E., Husain, W., San, O. Y., Almomani, A., \& Al-Betar, M. (2014). Mobile game approach to prevent childhood obesity using persuasive technology. Paper presented at the 2014 International Conference on Computer and Information Sciences (ICCOINS).

Aziz, N., Salleh, S., Yusof, Y., \& Roseli, N. (2017). Persuasive technology as intervention programs for Health care in Malaysia: a review. Journal of Fundamental and Applied Sciences, 9(6S), 991-1001.

Butt, J., Saleem, H., Siddiqui, A., Saleem, S., \& Awang, M. (2021). Influence of Social Media towards E-Participation of Youth in National Political Elections. International Journal of Management (IJM), ISSN: 0976-6510, Scopus Indexed, HEC Recognized" Y" Category Journal, 12(4), 734-748.

Faisal, S., Nor, A. A., \& Abdullah, N. (2019). Persuasive System Design for Global Acceptance of Smartphone Apps. Procedia Computer Science, 152, 44-50.

Fogg, B. J. (2002). Persuasive Technology: Using Computers to Change What We Think and Do. Ubiquity, 2002(December), 5.

Fogg, B. J. (2009). Creating Persuasive Technologies: An Eight-Step Design Process. Paper presented at the Proceedings of the 4th international conference on persuasive technology.

Hamid, N. A., Cheun, C., Abdullah, N., Ahmad, M., \& Ngadiman, Y. (2019). Does persuasive E-commerce website influence users' acceptance and online buying behaviour? The findings of the largest E-commerce website in Malaysia. In ICT for a Better Life and a Better World (pp. 263-279): Springer.

Hassan, S., Shiratuddin, N., \& Ab Salam, S. N. (2015). Social media as persuasive technology for business in Malaysia. International Journal of E-Business Research (IJEBR), 11(2), 18-39

Ishak, N., Khairuddin, F. N., \& Aziz, N. S. (2020). Social media use intensity at workplace among human resources executives of a government agency headquarters in Kuala Lumpur, Malaysia. e-Academia Journal, 9(1)

Mohamad, M., Yahaya, W. A. J. W., \& Wahid, N. A. (2018). The Preliminary Study of a Mobile Health Application for Visual Impaired Individual. Paper presented at the Proceedings of the 2nd International Conference on Education and Multimedia Technology.

Muhamad, M. K. A. B., \& Shahrom, M. (2020). The effects of the elements in social media content on social media engagement behaviour among youth. Romanian Journal of Information Technology and Automatic Control, 30(4), 63-72.

Nawi, N. B. C., Nasir, N. A. B. M., \& Al Mamun, A. (2016). Factors contributing to the acceptance of social media as a platform among student entrepreneurs: A review. Mediterranean Journal of Social Sciences, 7(2), 42

Noor, N. S. F. B. M., \& Shahrom, M. (2021). The effect of social media usage on employee job performance. Romanian Journal of Information Technology and Automatic Control, 31(1), 65-76

Orji, R., Vassileva, J., \& Mandryk, R. L. (2014). Modeling the efficacy of persuasive strategies for different gamer types in serious games for health. User Modeling and UserAdapted Interaction, 24(5), 453-498.

Oyibo, K., Orji, R., \& Vassileva, J. (2017). Investigation of the persuasiveness of social influence in persuasive technology and the effect of age and gender. Paper presented at the International Workshop on Persuasive Technology (Amsterdam, 2017).

Puad, N. H. M., Rahim, N. A., Firdaus, K. H. A., Sayedi, N., \& Mohadis, H. M. (2019). Designing a Persuasive Application for Behaviour Change with Children. Journal of Marketing and Information Systems, 2(2), 1-7.

Qasim, M. M., Ahmad, M., Omar, M., Zulkifli, A. N., \& Bakar, J. A. A. (2017). A systematic process for persuasive mobile healthcare applications. Paper presented at the AIP Conference Proceedings.

Rahman, S. M. b. A. (2016). The Effective Use of Video in Social Media as Persuasive Technology for Charity. Kuliyyah of Information and Communication Technology, International Islamic ....

Salim, M. H. M., Ali, N. M., \& Noah, S. A. M. (2017). Mobile application on healthy diet for elderly based on persuasive design. International Journal on Advanced Science, Engineering and Information Technology, 7(1), 222-227.

Stinson, P. M. (2021). Document Analysis. The Encyclopedia of Research Methods in Criminology and Criminal Justice, 1, $392-394$.

Taha, A., Wu, R., Emeakaroha, A., Krabicka, J., \& Lee, A. (2017). Inducing pro-environmental behaviour in National Health Service (NHS) to reduce energy costs using persuasive technology techniques. Paper presented at the 16th International Conference on Sustainable Energy Technologies.

Wan Ahmad, W. N., \& Ali, N. M. (2018). A Study on Persuasive Technologies: The Relationship between User Emotions, Trust and Persuasion. International Journal of Interactive Multimedia \& Artificial Intelligence, 5(1).

Yahaya, W. A. J. W., \& Hashim, M. (2018). ENHANCING PRIMARY SCHOOL STUDENTS KNOWLEDGE AND AWARENESS OF OBESITY RISK: INTEGRATING MULTIMEDIA DESIGN PRINCIPLES IN DESIGNING APPLICATION OF PERSUASIVE MULTIMEDIA. Uluslararası Bilimsel Araştırmalar Dergisi (IBAD), 1-10.

Çakiroğlu, Ü., \& Gökoğlu, S. (2019). A design model for using virtual reality in behavioural skills training. Journal of Educational Computing Research, 57(7), $1723-1744$. 